Discussion Paper Series A No.693

Structural Change, Capital Deepening, and TFP Growth in Japan: $1885-1970$

Kyoji Fukao

(Hitotsubashi University and IDE-JETRO)

Tatsuji Makino

(Hitotsubashi University)

and

Tokihiko Settsu

(Musashi University)

May 2019

Institute of Economic Research

Hitotsubashi University

Kunitachi, Tokyo, 186-8603 Japan 


\title{
Structural Change, Capital Deepening, and TFP Growth in Japan: 1885-1970
}

May 2019

Kyoji Fukao

(Hitotsubashi University and IDE-JETRO)

\author{
Tatsuji Makino \\ (Hitotsubashi University) \\ Tokihiko Settsu \\ (Musashi University)
}

\begin{abstract}
After the Meiji Restoration of 1868, Japan modernized its institutions and economic growth gradually picked up. Growth accelerated especially during the so-called highspeed growth era from 1955 to 1970, when Japan rapidly caught up with Western economies. The long-term sustained high-speed growth recorded during this period was unprecedented not only in Japan but worldwide. While other East Asian countries such as Singapore, Taiwan, South Korea, and China subsequently also experienced remarkable growth over a prolonged period, Japan's place in history as the first country to record such sustained high-speed growth means that its experience continues to garner worldwide interest. Using newly constructed Hitotsubashi estimates of Japan's historical GDP statistics and a growth accounting framework, we analyze the sources of Japan's economic growth from 1885 to 1970 and try to answer why Japan was not able to accomplish such high-speed growth before 1955. Since until the mid-1960s the primary sector accounted for a large share of economic activity and was a major determinant of overall economic growth, we use a Hayashi and Prescott (2008) type two-sector model in which the economy overall is divided into the primary sector and the non-primary sector.
\end{abstract}




\section{Introduction}

Following the Meiji Restoration of 1868, Japan as the first country in Asia embarked on modern economic growth (Maddison 2006, 2007) and by around 1970 had almost caught up with major European countries such as the UK, Germany, and France in terms of per capita gross domestic product (GDP). Using newly constructed Hitotsubashi estimates of Japan's historical GDP statistics, Hitotsubashi University's Long-Term Economic Statistics (LTES), and other statistics (a detailed description of data sources is provided in Appendix 1), this study examines Japan's economic growth from 1885 to 1970 employing a growth accounting framework.

In what Ohkawa (1969) referred to as “trend acceleration," Japan's economic development until around 1970 was characterized by a steady acceleration of economic growth. As shown in Figure 1, in the high-speed growth (HSG) era (1955-70), Japan achieved rapid and sustained growth that was unprecedented in the world (Komiya 1975, chapter 1). On the other hand, before World War II, Japan's rate of per capita GDP growth was not substantially higher than that of the United States and Britain. Looking at the period from 1885 to 1970 overall, but excluding World War II and the economic turmoil that entailed (1940-55), a comparison of the average annual per capita GDP growth rates of Japan, Britain, and the United States shows that during the Meiji period (1885-1913), when Japan first embarked on modern economic growth, Japan's growth rate at 1.2 percent was more or less on par with Britain's (1.1 percent) but behind that of the United States (1.7 percent). However, during the Taisho and early Showa period (1913-1940), when manufacturing industry led by the heavy and chemical industries expanded spurred by import substitution and military demand as a result of World War I, Japan's average annual per capita GDP growth rate at 2.6 percent started to outpace those of Britain (1.2 percent) and the United States (1.0). Finally, during the HSG era, Japan's annual per capita GDP growth, at 8.4 percent, outstripped that of Britain and the United States (both 2.1 percent) by a factor of four. 
Figure 1. Trends in per capita GDP (1990 international US dollars): Comparison of Japan, the United States, and the United Kingdom, 1874-2010

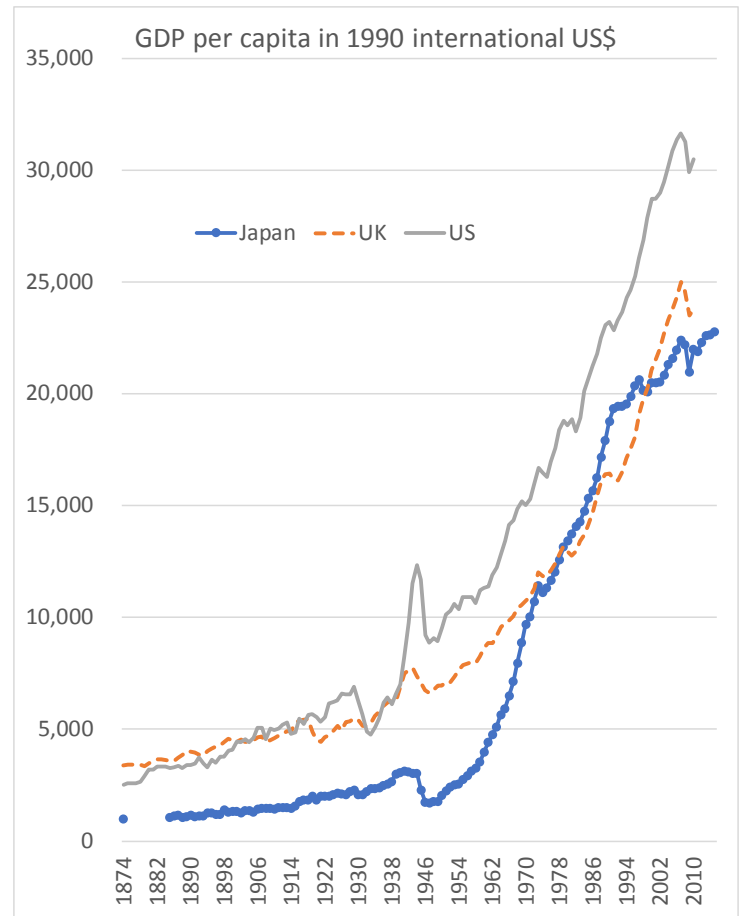

Sources: For Japan, see Appendix 1. For the United States and the United Kingdom: New Maddison Project Database 2013,

https://www.rug.nl/ggdc/historicaldevelopment/maddison/releases/maddison-project-database-2013.

The HSG era was characterized by another important feature that sets it apart from the prewar period. As highlighted by Hayashi and Prescott (2008), the HSG era saw unprecedentedly rapid structural change and a large decline in the factor input and valueadded shares of the primary sector (see Figures 2 and 3).

If capital and labor shift to industries offering higher returns, this increases the efficiency of resource allocation in the economy overall and to that extent raises GDP. Therefore, in order to examine the extent to which the reallocation of resources contributed to Japan's economic growth during the HSG era, we divide the economy overall into the primary sector and the non-primary sector and conduct growth accounting. ${ }^{1}$

\footnotetext{
1 This study is not the first to conduct historical growth accounting for the Japanese economy. Examples of previous growth accounting exercises on Japan include Hayami (1973) focusing on agriculture for the period from the Meiji era onward, Ohkawa and Rosovsky (1973) focusing on agriculture, mining and manufacturing, utilities, construction, and services, and Minami and Makino (2002) focusing on the
} 


\section{Figure 2. Sectoral shares of labor input in Japan}

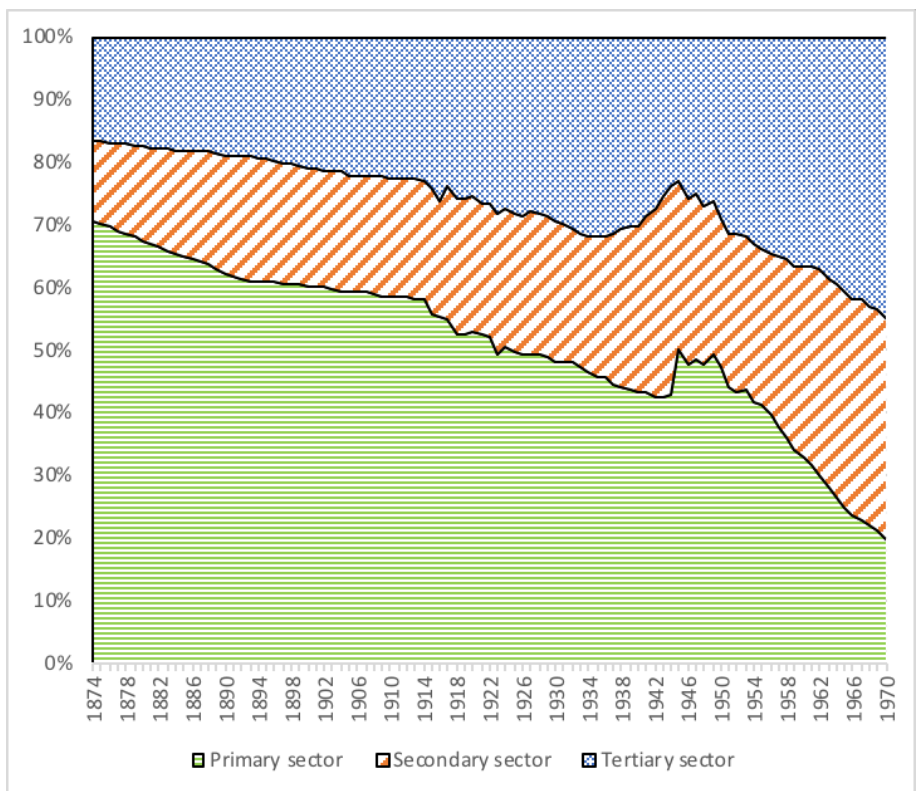

Source: See Appendix 1. Labor input is measured in terms of the number of workers.

\section{Figure 3. Sectoral shares of nominal value added in Japan}

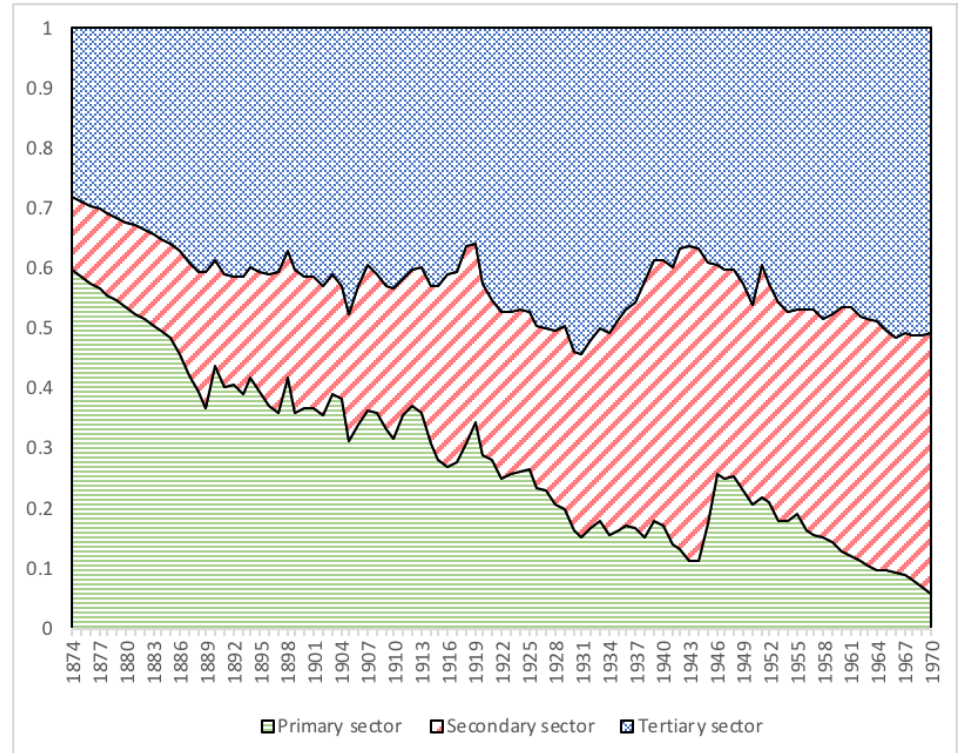

Source: See Appendix 1.

primary sector and mining and manufacturing. Further, Maddison (2007) conducted growth accounting from the Meiji period, although this was not at the industry level, but for all industries together. For industry-level growth accounting for the period from 1955 onward, see Jorgenson, Nomura, and Samuels (2016). 
Note: Figures for years for which no data are available are obtained through linear interpolation.

Details of the growth accounting framework taking resource allocation across sectors into account that we employ in this study can be found in Jorgenson et al. (2007). Other studies conducting analyses of Japan from the Meiji period onward from a similar perspective include Sonobe and Otsuka (2001) and Hayashi and Prescott (2006). However, both studies essentially are based on the original Long-Term Economic Statistics (LTES) and, as result, differ from the analysis in this study. For example, the original LTES do not take by-employment into account and overestimate the GDP growth rate before World War II. $^{2}$

The remainder of this study is organized as follows. The next section explains our growth accounting approach using a two-sector model and outlines the data used. Section 3 presents our growth accounting results. Finally, Section 4 summarizes the main findings of our analysis.

\section{Growth accounting approach and data used}

The growth accounting framework assuming a two-sector model we employ in this paper is as follows. We assume that labor $L_{p}$, capital $K_{p}$, and land $A_{p}$ are used as inputs in the primary sector, denoted by subscript $p$, and labor $L_{n}$ and capital $K_{n}$ are used as inputs in the non-primary sector, denoted by subscript $n$, to produce real value added $Y_{p}$ and $Y_{n}$. Assuming that the production functions in the two sectors are characterized by constant

\footnotetext{
${ }^{2}$ Note that although the analysis by Jorgenson, Nomura, and Samuels (2016) mentioned in footnote 1 and studies using the Japan Industrial Productivity (JIP) database from 1970 onward (e.g., Fukao et al., 2008) conduct growth accounting analyses at the industry level, they do not examine the effect of resource reallocation, since they assume that the production factors used as input in different industries differ from each other. For example, whereas the present study regards an increase in GDP due to workers shifting from low-wage industries to high-wage industries as an increase in TFP due to improved allocation of labor across industries, Jorgenson, Nomura, and Samuels (2016) and Fukao et al. (2008) regard this as reflecting an increase in labor input due to a rise in labor quality. See Jorgenson et al. (2007) for details on the differences between such growth accounting approaches. Similarly, it is highly likely that in Jorgenson, Nomura, and Samuels (2016) the effect of improvements in the allocation of capital across industries is regarded as part of the increase in capital input due to a rise in the quality of capital.
} 
returns to scale, are sufficiently smooth, and inputs of production factors also change smoothly over time, the growth rate of real value added (the growth rate from the current year to the following year, calculated as the log difference) can be approximated as follows:

$\widehat{Y}_{p}=\bar{S}_{K, p} \widehat{K}_{p}+\bar{s}_{L, p} \hat{L}_{p}+\bar{s}_{A, p} \hat{A}_{p}+\hat{Z}_{p}$

$\hat{Y}_{n}=\bar{s}_{K, n} \widehat{K}_{n}+\bar{s}_{L, n} \hat{L}_{p}+\hat{Z}_{n}$

where $\wedge$ denotes the rate of change in a variable (calculated as the log difference), ${ }^{-}$denotes the average of the values of a variable in the current year and the following year, $s_{j, i}$ represents the input share of factor $j$ in industry $i$, and $Z_{i}$ represents total factor productivity (TFP) in industry $i$. The sum of the share of all production factors $s_{j, i}$ in each sector by definition equals one. Subtracting the growth rate of labor input in each sector from both sides of the two equations and using the fact that the sum of input shares equals one yield the following equations:

$$
\begin{aligned}
& \hat{Y}_{p}-\widehat{L}_{p}=\bar{s}_{K, p}\left(\widehat{K}_{p}-\widehat{L}_{p}\right)+\bar{s}_{A, p}\left(\hat{A}_{p}-\widehat{L}_{p}\right)+\hat{Z}_{p} \\
& \hat{Y}_{n}-\hat{L}_{n}=\bar{s}_{K, n}\left(\widehat{K}_{n}-\widehat{L}_{n}\right)+\hat{Z}_{n}
\end{aligned}
$$

In the two equations, the left-hand side represents the growth rate of labor productivity in each sector, the first term on the right-hand side represents the effect of increases in the capital stock per worker on labor productivity, and the last term on the right-hand side is the TFP growth rate. The second term on the right-hand side of the first equation shows the effect of increases in land input per worker on labor productivity in the primary sector.

Next, we explain the growth accounting for the economy overall. Denoting the share of the primary sector in nominal GDP by $\theta_{p}$, the growth rate of real GDP $(Y)$ can be approximated using the following equation:

$$
\widehat{Y}=\bar{\theta}_{p} \widehat{Y}_{p}+\left(1-\bar{\theta}_{p}\right) \hat{Y}_{n}
$$

Since in growth accounting real GDP is calculated as a chain index as in equation (5), the growth rate calculated from the real GDP series in the appendix tables and the Hitotsubashi estimates mentioned in the first section differ slightly.

Substituting equations (1) and (2) into the right-hand side of equation (5) yields the following equation: 


$$
\begin{aligned}
& \hat{Y}=\bar{\theta}_{p} \bar{s}_{K, p} \widehat{K}_{p}+\left(1-\bar{\theta}_{p}\right) \bar{s}_{K, n} \widehat{K}_{n}+\bar{\theta}_{p} \bar{s}_{L, p} \hat{L}_{p}+\left(1-\bar{\theta}_{p}\right) \bar{s}_{L, n} \hat{L}_{n}+\bar{\theta}_{p} \bar{s}_{A, p} \hat{A}_{p}+\bar{\theta}_{p} \hat{Z}_{p} \\
& +\left(1-\bar{\theta}_{p}\right) \hat{Z}_{n}
\end{aligned}
$$

This equation is a growth accounting equation that decomposes the sources of macroeconomic growth from the supply side. The first two terms on the right-hand side show the contribution of capital accumulation in the two sectors, the next two terms represent the contribution of increases in labor input in the two sectors, the fifth term shows the contribution of increases in land input, and the last two terms show the contribution of TFP growth in the two sectors. The first two terms on the right-hand side can be approximated as follows:

$$
\begin{aligned}
\bar{\theta}_{p} \bar{s}_{K, p} \widehat{K}_{p} & +\left(1-\bar{\theta}_{p}\right) \bar{s}_{K, n} \widehat{K}_{n}=\bar{s}_{K} \widehat{K}+\frac{K_{p}}{G}\left(\frac{\bar{s}_{K, p} \bar{\theta}_{p} G}{K_{p}}-\frac{\bar{s}_{K} G}{K}\right)\left(\widehat{K}_{p}-\widehat{K}\right) \\
& +\frac{K_{n}}{G}\left(\frac{\bar{s}_{K, n} \bar{\theta}_{n} G}{K_{n}}-\frac{\bar{s}_{K} G}{K}\right)\left(\widehat{K}_{n}-\widehat{K}\right)
\end{aligned}
$$

where $s_{K}$ is the income share of capital in the economy overall, $K$ is the capital stock in the economy overall, and $G$ is nominal GDP. The first term on the right-hand side represents the contribution of increases in the capital stock to economic growth when capital stock in the two sectors grows at the same rate (in this case, the rate of growth of capital stock in each sector is equal to the rate of growth of capital stock in the economy overall). The second term in parentheses represents the difference between the return on capital in the primary sector and the average return on capital in the economy overall. This term shows that when the return on capital in the primary sector is low, economic growth will accelerate if the growth rate of capital stock in the primary sectors rate falls below that in the economy as a whole. The third term is the corresponding term for the non-primary sector. The sum of the second and third terms represents the effect of increases in TFP due to efficiency gains reflecting the reallocation of capital across sectors. We abbreviate this as $\Omega_{K}$.

Similarly, the third and fourth terms in equation (6) can be approximated as follows:

$$
\bar{\theta}_{p} \bar{s}_{L, p} \hat{L}_{p}+\left(1-\bar{\theta}_{p}\right) \bar{s}_{L, n} \hat{L}_{n}=\bar{s}_{L} \hat{L}+\frac{L_{p}}{G}\left(\frac{\bar{s}_{L, p} \bar{\theta}_{p} G}{L_{p}}-\frac{\bar{s}_{L} G}{L}\right)\left(\hat{L}_{p}-\hat{L}\right)
$$




$$
+\frac{L_{n}}{G}\left(\frac{\bar{s}_{L, n} \bar{\theta}_{n} G}{L_{n}}-\frac{\bar{s}_{L} G}{L}\right)\left(\hat{L}_{n}-\hat{L}\right)
$$

where $s_{L}$ is the income share of labor in the economy overall and $L$ is the input of labor in the economy overall. As in the case of capital, the sum of the second and third terms on the right-hand side represent the increase in TFP due to efficiency gains reflecting the reallocation of labor across sectors. We abbreviate this as $\Omega_{L}$. Meanwhile, regarding the factor income shares in the economy overall, the following equation holds:

$$
\bar{s}_{K}+\bar{s}_{L}+\bar{\theta}_{p} \bar{s}_{A, p}=1
$$

Subtracting the growth rate of labor input $L$ in the economy overall from both sides of equation (5) and using the above relationship, we obtain

$$
\hat{Y}-\hat{L}=\bar{s}_{K}(\widehat{K}-\hat{L})+\bar{\theta}_{p} \bar{s}_{A, p}\left(\hat{A}_{p}-\hat{L}\right)+\bar{\theta}_{p} \hat{Z}_{p}+\left(1-\bar{\theta}_{p}\right) \hat{Z}_{n}+\Omega_{K}+\Omega_{L}
$$

This is the equation that we use for our growth accounting for the economy overall. The left-hand side of this equation represents the growth rate of labor productivity in the economy. The first term on the right-hand side shows the contribution of increases in capital input per worker in the economy overall, the second term is the contribution of increases in land input per worker in the economy overall, the third term is the contribution of TFP growth in the primary sector, the fourth term the contribution of TFP growth in the non-primary sector, the fifth term the effect of TFP increases due to efficiency improvements as a result of the reallocation of capital, and the sixth term is the effect of TFP increases due to efficiency improvements as a result of the reallocation of labor.

Due to data constraints for the prewar period, labor input in the prewar period is measured in terms of the number of gainfully occupied persons, while in the postwar period it is measured in terms of the number of employed persons. For this reason, the contribution of increases in working hours per worker as well as increases in the quality of labor due to rising education levels and improved skills to GDP growth in our growth accounting framework are included in TFP growth. Moreover, capital input is measured in terms of the capital stock, not capital services (the difference between the two represents 
improvements in capital quality). ${ }^{3}$ For the HSG era, data on the contribution of increases in the quality of labor and capital are available, and taking the quality of labor and capital into account allows us to examine the extent to which this affects our growth accounting results. This point will be discussed in more detail below.

The data used for the growth accounting analysis are shown in Appendix Tables 1 and 2. These data are taken from Fukao and Settsu (2017b, 2017d, 2018) and Fukao (2018). The following is a brief outline of how the data were constructed. For details, refer to these chapters.

Let us start by explaining the data for 1885 to 1940 (Appendix Table 1). Real value added and the number of gainfully occupied persons in the primary and the non-primary sector are taken from Fukao and Settsu (2017b, 2017d) (changes in working hours are not taken into account). These data were estimated by Bassino, Fukao, and Settsu (2016) and Fukao et al. (2015).

For primary sector capital stock, Fukao and Settsu (2017b, 2017d) use the net capital data on agricultural plants and animals as well as agricultural machinery from table 29 in Umemura et al. (1966: 212-213) and the net capital data for forestry and fisheries from table 4 in Ohkawa et al. (1966: 156-159. As for small-farming implements in agriculture, since Ohkawa et al. (1974) switched to the principle of not including them in the capital stock of agriculture, Fukao and Settsu follow their principle. For agricultural nonresidential building structures, Fukao and Settsu convert the series in table 5-18 in

\footnotetext{
${ }^{3}$ Firms invest not only in capital stock with low rates of depreciation, such as buildings and structures, but also in capital stock such as machinery and facilities that depreciate relatively quickly and may give rise to capital losses due to a fall in prices as a result of technological innovation. The reason why firms invest in the latter is that they are expected to make a large contribution to output that is commensurate with the high input cost. Therefore, even if capital goods have the same market value, they have differing input costs, and capital goods with higher input costs should contribute more to output. Thus, the idea underlying the concept of capital services is to estimate the capital services provided by each type of capital good taking input costs into account and then aggregating these capital services. If the share of capital goods with high input costs increases, capital service input will be higher even if the amount of capital stock is the same. The increase in capital service input due to such structural change in capital is called the increase in capital quality.
} 
Ohkawa et al. (1974: 92) into net capital. Fukao and Settsu treat the sum of these different types of capital as the primary sector capital stock. Meanwhile, the capital stock of the non-primary sector is the sum of the total net capital stock in table 5 in Ohkawa et al. (1966: 160-163) and the total net capital stock in table 6 (farm houses and non-farm houses) on pages 164-165 in the same volume. For land input in the primary sector, Fukao and Settsu use the arable land area from Hayami (1973: 205-207, appendix table C-4).

For cost shares of labor and land in the primary sector, Fukao and Settsu (2017b, 2017d) follow the estimation approach for cost shares in gross agricultural output in Hayami (1973: 37, table 2-7) and use these to calculate the cost shares of labor and land in value added. The cost share of labor in the non-primary sector (including labor income from self-employment) is taken from Ohkawa and Minami (1975: 616-617, appendix table 18). Since Ohkawa and Minami's estimates cover only the private sector, we assume that the cost share of labor in the government sector is identical.

Next, we briefly outline our data for the period 1940-1970 (Appendix Table 2). Data for value added (both nominal and real) as well as the number of gainfully occupied persons and the number of employed persons, as described in Fukao and Settsu (2018), are constructed by linking data from Keizai Shingicho (1954), 1965 benchmark year national income statistics, 1990 benchmark year national accounts, Mizoguchi and Nojima (1993), and other sources. Moreover, the estimates of the income shares of labor, capital, and land, like those in Appendix 1, are obtained following Hayami (1973) and Ohkawa and Minami (1975).

On the other hand, statistics, source materials, and analyses with regard to capital stock especially for the period 1940-1955, i.e., much of World War II and the economic turmoil that followed - are in short supply, and even the LTES only provide estimates for the primary sector (private, non-enterprises). Therefore, in order to capture the capital stock for Japan as a whole, it is necessary to additionally estimate capital stock for private enterprises (non-primary sector), housing (private sector and government sector), and government (excluding housing; including social overhead capital such as roads and highways, erosion and flood control, etc.). Fukao and Settsu (2018) use data from Economic Planning Agency (1966) for the capital stock of private enterprises and extrapolate the data backward to 1940 and forward to 1970. Moreover, for housing and government, Fukao and Settsu (2018) construct investment data and deflators from the LTES, 1965 benchmark year national income statistics, 1990 benchmark year national 
accounts, and Economic Planning Agency (1986) and employ these to estimate capital stocks using the perpetual inventory method.

Finally, note that the primary sector capital in Appendix Table 2 equals the sum of the primary sector capital stock in the LTES and the part of government capital stock that forms part of the primary sector (capital stock related to the primary sector such as infrastructure for agriculture, etc.). On the other hand, the non-primary sector capital stock in Appendix Table 2 equals the sum of the capital stock of private enterprises, housing (private sector and government), government (everything except housing and transfers to the primary sector).

\section{Supply-side analysis of the sources of economic growth: 1885-1970}

The results of our growth accounting analysis are shown in Tables 1 to 3 and Figures 4 to 6 .

Let us start by looking at the results for the economy overall (see Table 1 and Figure 4). The second column (column (a)) in Table 1 shows the growth rate of labor productivity (period average, annualized, the same applies to other growth rates below). The next three columns ((b) to (d)) break this down into the contribution of increases in the capital stock per worker, the contribution of increases in arable land area per worker, and the contribution of TFP growth. The next three columns ((e) to (g)) break down the TFP growth rate into the contribution of TFP increases within each sector and the contribution of the reallocation of labor and capital across sectors. Moreover, if we add the growth rate of the number of workers (column (h)) to the growth rate of labor productivity in the economy overall (column (a)), we obtain the growth rate of real GDP (column (i)). Furthermore, subtracting the population growth rate (column (j)) from the real GDP growth rate, we obtain the growth rate of real GDP per capita (column (k)). As the proportion of workers in the population rises, the rate of increase in GDP per capita will exceed the growth rate of labor productivity. This effect is represented by the last column (column (l)) in the table.

Comparing the growth accounting results for the different subperiods, we find that, as already mentioned in Section 1, and as shown by the solid line in Figure 4, Japan's GDP growth accelerated throughout the period, with the exception of 1940-1955, that is, the 
period of economic turmoil during and immediately after World War II. While the increase in the number of employed persons (represented by the difference between the solid and the dashed line) contributed to this, the main source of the acceleration of economic growth was the increase in labor productivity growth. Labor productivity growth accelerated from $1.77 \%$ during the Meiji period to $2.92 \%$ during the Taisho and early Showa period. During the HSG era, labor productivity growth further accelerated substantially, reaching $7.60 \%$.

Next, comparing the sources of labor productivity growth, as shown in Table 1, in all three periods, TFP growth made a larger contribution than increases in the capital stock per worker. Especially before World War II, increases in capital stock per worker contributed less than 1 percentage point, and TFP growth was the main engine of economic growth. On the other hand, during the HSG era, the contribution of increases in the capital stock per worker rose substantially, accounting for 2.64 percentage points of GDP growth. The main factor underlying TFP growth in all subperiods is the within effect, that is, the TFP growth within each sector, while improvements in the allocation of labor accounted for about one-fifth of TFP growth overall. Specifically, during the HSG era, the employment share of the primary sector, where wages were low, fell sharply, so that efficiency improvements due to the reallocation of labor across sectors accounted for 0.96 percentage points per year, which was considerably higher than during the prewar period. This had the effect of increasing GDP by 15\% during the HSG era (exp 0.0096 $\times 15)=1.15$ ). On the other hand, the impact of capital reallocation was relatively small in all periods. The area of arable land per worker in the economy overall has decreased since the Taisho period, so that the contribution of arable land per worker has been negative since the Taisho period.

Turning to the growth accounting results by sector, the results for the non-primary sector are shown in Table 2 and Figure 5 and indicate that, more or less like in the economy overall, TFP growth and increases in the capital stock per worker, which both gradually accelerated, drove the expansion of real output. In the prewar period, increases in capital stock per worker made a relatively large contribution especially in the years from 1899 to 1913 , when Japan was making steady progress on the road to modern economic growth in the wake of the first so-called "enterprise boom" (kigyo bokko, 1886-1890) and the First Sino-Japanese War (1894-95). While this is consistent with developments such as the spread of machine reeling in the silk industry, what specific changes in other industries such as services or transport and communication played a role is something that remains 
to be investigated in detail. Moreover, apart from TFP growth and increases in capital stock per worker, increases in the number of workers reflecting the inflow of workers from the primary sector essentially throughout the entire period from 1885 to 1970 considerably contributed to output growth in the primary sector. (The only exception is the period of World War II, when many moved from the cities to the countryside and back into agriculture.)

Next, the results for the primary sector are shown in Table 3 and Figure 6. Starting with the prewar period, labor productivity grew considerably in the years from 1899 to 1926. However, whereas in the first half of this period (1899-1913), this was almost entirely due to increases in TFP, in the latter half (1913-1926), increases in the capital stock per worker and the arable land area per worker also made a relatively large contribution. The findings indicate that the spread of Meiji noho (agricultural methods), which systemized conventional agricultural technologies based on interaction among farmers, scientists, and agricultural supply firms (Hayami and Ruttan, 1985: 237, Francks 1984), in the first half of this period contributed considerably to the increase in labor productivity. ${ }^{4}$ On the other hand, the results suggest that in the latter half of the period the contribution of increases in arable land and in the capital stock of agricultural tools, etc. was relatively large. However, how this is linked to the convergence to medium-sized farms (chuno hyojunka), which occurred during the interwar period, is something that requires further investigation in the future. ${ }^{5}$ Meanwhile, in the postwar period, TFP growth in the primary sector was quite strong until around 1965, which probably reflects recovery from the drop in TPF as a result of World War II. However, TFP declined during the period 1965-70. Moreover, while labor input declined sharply after the war, real output was supported by increases in capital stock per worker.

Thus, the growth accounting results show that the acceleration of Japan's trend growth was brought about, firstly, by the acceleration in within-sector TFP growth mainly in the non-primary sector and, secondly, by the fact that the contribution of the growth in capital stock per worker greatly increased, especially during the HSG era. To illustrate this, Figure 7 shows the cumulative contribution of increases in production factors and TFP to labor productivity growth in the economy overall. It should be noted that in the figure, labor productivity growth equals the product of each of these factors (i.e., increase in

\footnotetext{
4 Arimoto and Sakane (2017), Yagi (1990).

5 Sakane and Arimoto (2017), Yagi (1990).
} 
production factors and TFP). Looking at the cumulative effect from 1885 to 1970, labor productivity rose almost 9-fold: TFP growth had the effect of tripling labor productivity, increases in the capital stock per worker had the effect of doubling labor productivity, and improvements in the allocation of labor across industries raised labor productivity 1.4fold ( $3 \times 2 \times 1.4=8.4$ ). Other effects, that is, increases in arable land area per worker and the reallocation of capital only had a negligible effect, each accounting for less than $2 \%$ of the cumulative increase over the period as a whole.

Our growth accounting has shown that the main source of economic growth not only during the HSG era but also during the interwar period and even the Meiji period was the TFP growth within each sector. It should be noted, however, that in our analysis, as mentioned earlier, we measure labor input in terms of the number of workers and capital input in terms of capital stock, so that it is possible that the TFP growth we measure includes the effect of increases in working hours per worker and in the quality of labor and capital (see footnote 3).

For the period from 1955 onward, we can check the impact of quality improvements, since data and preceding studies measuring the quality of labor and capital are available. According to our estimate using the Population Census and other sources, increases in labor quality raised labor productivity at an annual rate of $0.82 \%$ during the HSG era (1955-70). In contrast, increases in working hours per worker played hardly any role during this period. Meanwhile, table 13.3 in Jorgenson, Nomura, and Samuels (2016) suggests that increases in the quality of capital during the HSG period raised TFP growth by more than 1 percentage point. Taken together, these results suggest that about $40 \%$ of the TFP growth rate of $5.02 \%$ (annual average rate, including the contribution of improvements in factor allocation across sectors) in the HSG period we measured (Table 3) was due to increases in the quality of labor and capital (including the contribution of improvements in factor allocation across sectors). ${ }^{6}$

\footnotetext{
${ }^{6}$ According to table 13.3 in Jorgenson, Nomura, and Samuels (2016), improvements in labor quality raised the labor productivity growth rate by 0.89 percentage points during the HSG growth era (1955-70). However, as mentioned in footnote 2, it should be noted that their estimates of the contribution of labor and capital quality improvements likely include the contribution of improvements in the allocation of labor and capital across sectors to economic growth.
} 
Table 1. Growth accounting results for the economy overall: 1885-1970 (period averages, annualized rates)

\begin{tabular}{|c|c|c|c|c|c|c|c|c|c|c|c|c|}
\hline & $\begin{array}{l}\text { Labor } \\
\text { productivity } \\
\text { growth }\end{array}$ & $\begin{array}{l}\text { Contributio } \\
\mathrm{n} \text { of } \\
\text { increases in } \\
\text { capital stock } \\
\text { per worker }\end{array}$ & $\begin{array}{l}\text { Contributio } \\
\mathrm{n} \text { of } \\
\text { increases in } \\
\text { arable land } \\
\text { per worker }\end{array}$ & TFP growth & $\begin{array}{l}\text { Contribution } \\
\text { of within- } \\
\text { sector TFP } \\
\text { growth }\end{array}$ & $\begin{array}{l}\text { TFP growth } \\
\text { due to } \\
\text { reallocation } \\
\text { of labor } \\
\text { across } \\
\text { sectors }\end{array}$ & $\begin{array}{l}\text { TFP growth } \\
\text { due to } \\
\text { reallocation } \\
\text { of capital } \\
\text { across } \\
\text { sectors }\end{array}$ & $\begin{array}{l}\text { Increase in } \\
\text { the number } \\
\text { of workers }\end{array}$ & $\begin{array}{l}\text { Real GDP } \\
\text { growth rate }\end{array}$ & $\begin{array}{l}\text { Population } \\
\text { growth rate }\end{array}$ & $\begin{array}{l}\text { Increase in } \\
\text { per capita } \\
\text { GDP }\end{array}$ & $\begin{array}{l}\text { Rate of } \\
\text { change in } \\
\text { the share of } \\
\text { workers in } \\
\text { the total } \\
\text { population }\end{array}$ \\
\hline & $\mathrm{a}=\mathrm{b}+\mathrm{c}+\mathrm{d}$ & b & c & $\mathrm{d}=\mathrm{e}+\mathrm{f}+\mathrm{g}$ & e & $\mathrm{f}$ & g & $\mathrm{h}$ & $\mathrm{i}=\mathrm{a}+\mathrm{h}$ & $\mathrm{j}$ & $k=i-j$ & $l=h-j$ \\
\hline 1885-1899 & $1.75 \%$ & $0.29 \%$ & $0.00 \%$ & $1.47 \%$ & $1.19 \%$ & $0.27 \%$ & $0.00 \%$ & $0.56 \%$ & $2.31 \%$ & $0.94 \%$ & $1.36 \%$ & $-0.38 \%$ \\
\hline 1899-1913 & $1.80 \%$ & $0.62 \%$ & $0.03 \%$ & $1.15 \%$ & $1.02 \%$ & $0.12 \%$ & $0.02 \%$ & $0.46 \%$ & $2.26 \%$ & $1.21 \%$ & $1.04 \%$ & $-0.76 \%$ \\
\hline $1926-1940$ & $2.82 \%$ & $0.81 \%$ & $-0.04 \%$ & $2.05 \%$ & $1.69 \%$ & $0.32 \%$ & $0.04 \%$ & $1.02 \%$ & $3.84 \%$ & $1.17 \%$ & $2.66 \%$ & $-0.16 \%$ \\
\hline 1940-1945 & $-2.46 \%$ & $-0.76 \%$ & $0.01 \%$ & $-1.71 \%$ & $-0.60 \%$ & $-0.78 \%$ & $-0.33 \%$ & $-2.19 \%$ & $-4.65 \%$ & $0.04 \%$ & $-4.68 \%$ & $-2.23 \%$ \\
\hline $1945-1950$ & $-3.93 \%$ & $-0.74 \%$ & $-0.04 \%$ & $-3.15 \%$ & $-3.46 \%$ & $0.33 \%$ & $-0.01 \%$ & $4.26 \%$ & $0.33 \%$ & $2.89 \%$ & $-2.56 \%$ & $1.36 \%$ \\
\hline 1950-1955 & $4.52 \%$ & $0.80 \%$ & $-0.04 \%$ & $3.76 \%$ & $2.87 \%$ & $0.80 \%$ & $0.09 \%$ & $2.15 \%$ & $6.67 \%$ & $1.41 \%$ & $5.26 \%$ & $0.74 \%$ \\
\hline $1955-1960$ & $6.14 \%$ & $1.51 \%$ & $-0.08 \%$ & $4.71 \%$ & $3.33 \%$ & $1.22 \%$ & $0.17 \%$ & $2.19 \%$ & $8.33 \%$ & $0.91 \%$ & $7.43 \%$ & $1.28 \%$ \\
\hline 1960-1965 & $7.20 \%$ & $3.10 \%$ & $-0.06 \%$ & $4.16 \%$ & $2.92 \%$ & $1.03 \%$ & $0.21 \%$ & $1.78 \%$ & $8.98 \%$ & $1.01 \%$ & $7.97 \%$ & $0.76 \%$ \\
\hline $1965-1970$ & $9.46 \%$ & $3.33 \%$ & $-0.05 \%$ & $6.18 \%$ & $5.47 \%$ & $0.63 \%$ & $0.08 \%$ & $1.86 \%$ & $11.32 \%$ & $1.08 \%$ & $10.24 \%$ & $0.78 \%$ \\
\hline Meiji: 1885-1913 & $1.77 \%$ & $0.45 \%$ & $0.01 \%$ & $1.31 \%$ & $1.11 \%$ & $0.19 \%$ & $0.01 \%$ & $0.51 \%$ & $2.28 \%$ & $1.08 \%$ & $1.20 \%$ & $-0.57 \%$ \\
\hline Taisho: 1913-26 & $3.02 \%$ & $0.84 \%$ & $-0.03 \%$ & $2.21 \%$ & $1.72 \%$ & $0.46 \%$ & $0.02 \%$ & $0.69 \%$ & $3.72 \%$ & $1.26 \%$ & $2.45 \%$ & $-0.57 \%$ \\
\hline HSG: 1955-70 & $7.60 \%$ & $2.64 \%$ & $-0.06 \%$ & $5.02 \%$ & $3.91 \%$ & $0.96 \%$ & $0.15 \%$ & $1.94 \%$ & $9.55 \%$ & $1.00 \%$ & $8.55 \%$ & $0.94 \%$ \\
\hline
\end{tabular}

Source: Authors’ calculations based on Appendix Tables 1 and 2. 
Figure 4. Sources of real GDP growth: 1885-1970 (period averages, annualized rates)

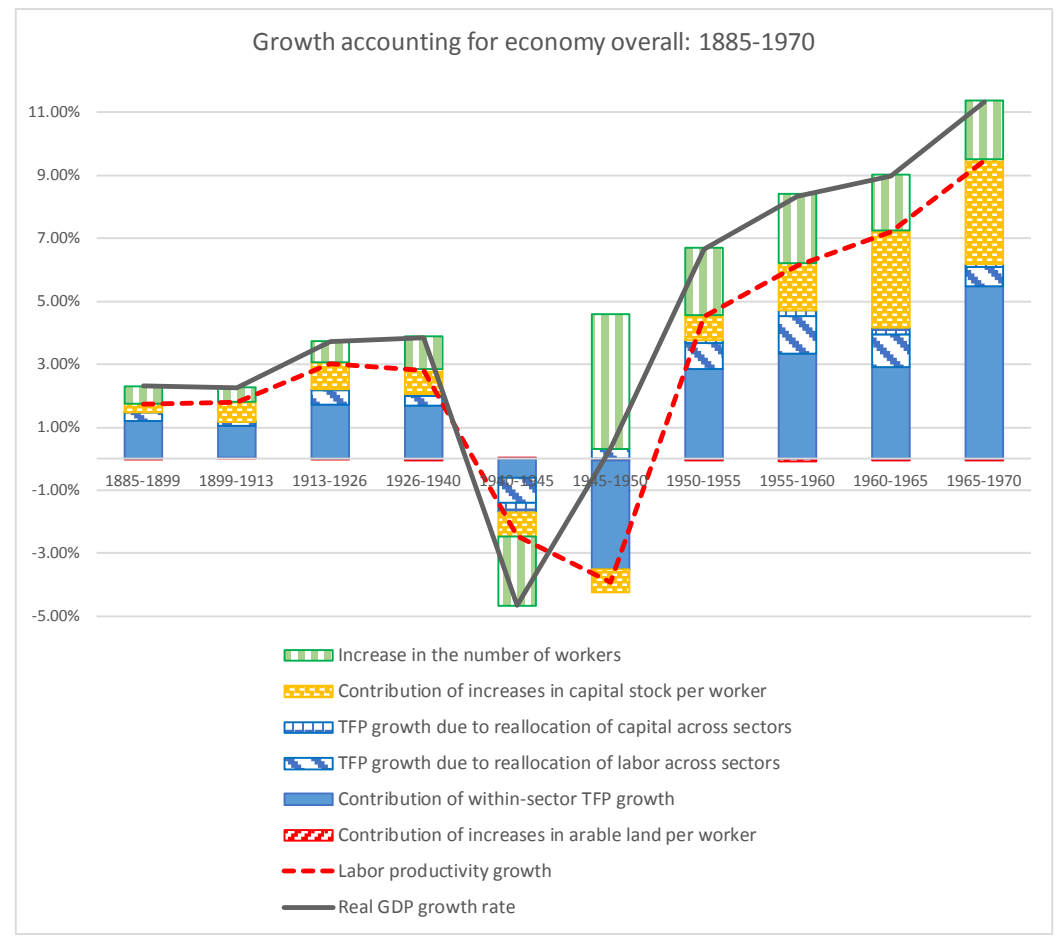

Source: See Table 1.

Table 2. Growth accounting results for the non-primary sector: 1885-1970 (period averages, annualized rates)

\begin{tabular}{|l|r|r|r|r|r|}
\hline & $\begin{array}{l}\text { Labor } \\
\text { productivity } \\
\text { growth }\end{array}$ & $\begin{array}{l}\text { Contribution of } \\
\text { increases in } \\
\text { capital stock } \\
\text { per worker }\end{array}$ & TFP growth & $\begin{array}{l}\text { Increase in } \\
\text { the number } \\
\text { of workers }\end{array}$ & $\begin{array}{l}\text { Increase in } \\
\text { real value } \\
\text { added }\end{array}$ \\
\hline & a b+c & b & c & d & e=a+d \\
\hline $1885-1899$ & $1.74 \%$ & $0.27 \%$ & $1.46 \%$ & $1.41 \%$ & $3.14 \%$ \\
\hline $1899-1913$ & $1.58 \%$ & $0.79 \%$ & $0.79 \%$ & $0.87 \%$ & $2.44 \%$ \\
\hline $1913-1926$ & $2.53 \%$ & $0.59 \%$ & $1.94 \%$ & $2.17 \%$ & $4.70 \%$ \\
\hline $1926-1940$ & $2.67 \%$ & $0.70 \%$ & $1.97 \%$ & $1.82 \%$ & $4.49 \%$ \\
\hline $1940-1945$ & $0.48 \%$ & $-0.03 \%$ & $0.51 \%$ & $-4.79 \%$ & $-4.31 \%$ \\
\hline $1945-1950$ & $-5.87 \%$ & $-1.33 \%$ & $-4.53 \%$ & $5.34 \%$ & $-0.53 \%$ \\
\hline $1950-1955$ & $2.85 \%$ & $0.50 \%$ & $2.35 \%$ & $4.26 \%$ & $7.11 \%$ \\
\hline $1955-1960$ & $4.48 \%$ & $1.22 \%$ & $3.27 \%$ & $4.86 \%$ & $9.34 \%$ \\
\hline $1960-1965$ & $6.01 \%$ & $2.94 \%$ & $3.07 \%$ & $4.04 \%$ & $10.05 \%$ \\
\hline $1965-1970$ & $9.29 \%$ & $3.18 \%$ & $6.11 \%$ & $3.19 \%$ & $12.48 \%$ \\
\hline Meiji: $1885-1913$ & $1.66 \%$ & $0.53 \%$ & $1.13 \%$ & $1.14 \%$ & $2.79 \%$ \\
\hline Taisho: $1913-26$ & $2.53 \%$ & $0.59 \%$ & $1.94 \%$ & $2.17 \%$ & $4.70 \%$ \\
\hline Prewar Showa: $1926-40$ & $2.67 \%$ & $0.70 \%$ & $1.97 \%$ & $1.82 \%$ & $4.49 \%$ \\
\hline HSG: $1955-70$ & $6.60 \%$ & $2.45 \%$ & $4.15 \%$ & $4.03 \%$ & $10.62 \%$ \\
\hline
\end{tabular}

Source: Authors’ calculations based on Appendix Tables 1 and 2. 
Figure 5. Sources of real value added growth in the non-primary sector: 1885-1970 (period averages, annualized rates)

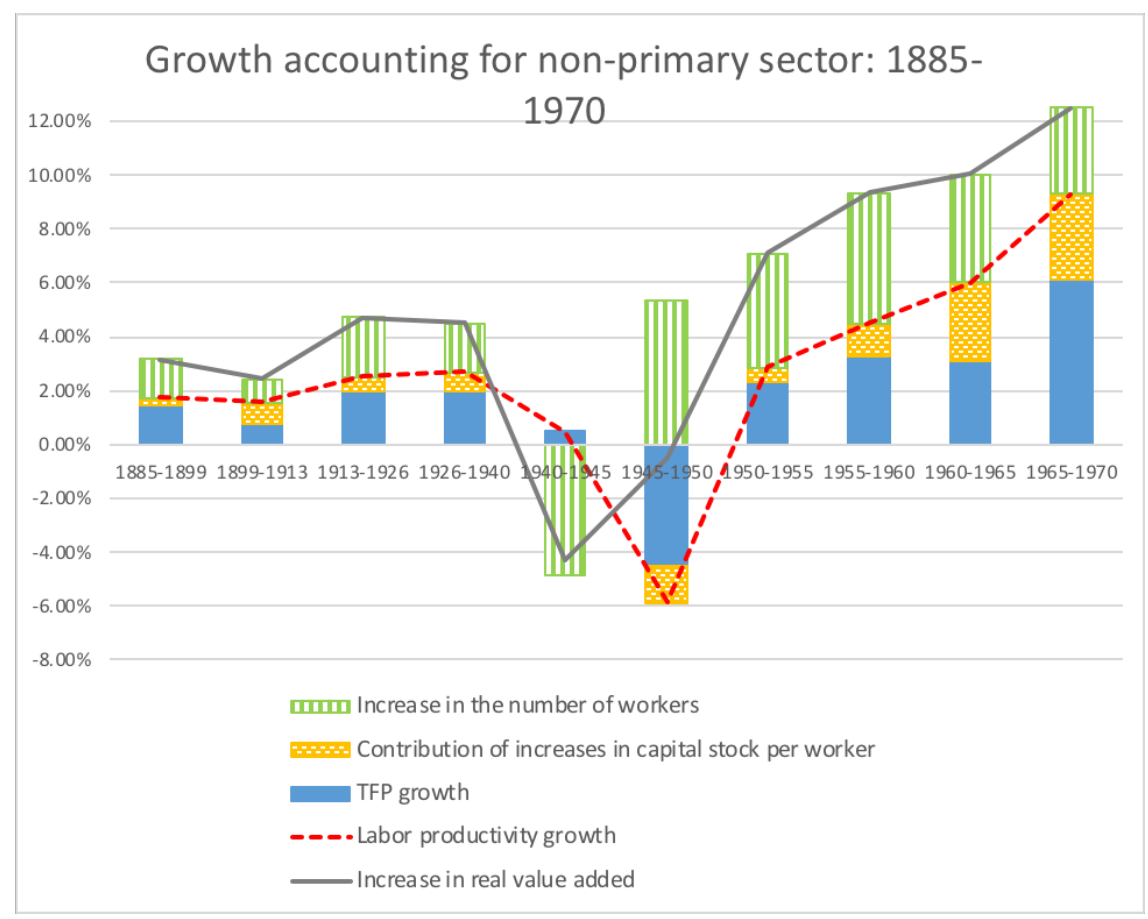

Source: See Table 2.

Table 3. Growth accounting results for the primary sector: 1885-1970 (period averages, annualized rates)

\begin{tabular}{|c|c|c|c|c|c|c|}
\hline & $\begin{array}{l}\text { Labor } \\
\text { productivity } \\
\text { growth }\end{array}$ & $\begin{array}{l}\text { Contribution of } \\
\text { increases in } \\
\text { capital stock } \\
\text { per worker }\end{array}$ & $\begin{array}{l}\text { Contributio } \\
\mathrm{n} \text { of } \\
\text { increases in } \\
\text { arable land } \\
\text { per worker }\end{array}$ & TFP growth & $\begin{array}{l}\text { Increase in the } \\
\text { number of } \\
\text { workers }\end{array}$ & $\begin{array}{l}\text { Increase in } \\
\text { real value } \\
\text { added }\end{array}$ \\
\hline & $\mathrm{a}=\mathrm{b}+\mathrm{c}+\mathrm{d}$ & b & C & d & e & $\mathrm{f}=\mathrm{a}+\mathrm{e}$ \\
\hline 1885-1899 & $0.82 \%$ & $0.07 \%$ & $0.15 \%$ & $0.60 \%$ & $0.05 \%$ & $0.88 \%$ \\
\hline 1899-1913 & $1.62 \%$ & $0.14 \%$ & $0.17 \%$ & $1.30 \%$ & $0.18 \%$ & $1.80 \%$ \\
\hline 1913-1926 & $1.47 \%$ & $0.32 \%$ & $0.29 \%$ & $0.86 \%$ & $-0.59 \%$ & $0.88 \%$ \\
\hline 1926-1940 & $0.50 \%$ & $0.24 \%$ & $0.06 \%$ & $0.21 \%$ & $0.08 \%$ & $0.58 \%$ \\
\hline 1940-1945 & $-7.52 \%$ & $-0.13 \%$ & $-0.22 \%$ & $-7.17 \%$ & $0.80 \%$ & $-6.71 \%$ \\
\hline 1945-1950 & $0.97 \%$ & $-0.12 \%$ & $-0.10 \%$ & $1.18 \%$ & $3.11 \%$ & $4.08 \%$ \\
\hline 1950-1955 & $5.54 \%$ & $0.45 \%$ & $0.03 \%$ & $5.07 \%$ & $-0.51 \%$ & $5.02 \%$ \\
\hline $1955-1960$ & $5.26 \%$ & $0.81 \%$ & $0.72 \%$ & $3.73 \%$ & $-2.34 \%$ & $2.91 \%$ \\
\hline 1960-1965 & $4.16 \%$ & $1.47 \%$ & $0.94 \%$ & $1.75 \%$ & $-3.83 \%$ & $0.33 \%$ \\
\hline 1965-1970 & $0.49 \%$ & $2.26 \%$ & $0.44 \%$ & $-2.22 \%$ & $-2.78 \%$ & $-2.29 \%$ \\
\hline Meiji: 1885-1913 & $1.22 \%$ & $0.11 \%$ & $0.16 \%$ & $0.95 \%$ & $0.11 \%$ & $1.34 \%$ \\
\hline Taisho: 1913-26 & $1.47 \%$ & $0.32 \%$ & $0.29 \%$ & $0.86 \%$ & $-0.59 \%$ & $0.88 \%$ \\
\hline Prewar Showa: 1926-40 & $0.50 \%$ & $0.24 \%$ & $0.06 \%$ & $0.21 \%$ & $0.08 \%$ & $0.58 \%$ \\
\hline HSG: 1955-70 & $3.30 \%$ & $1.51 \%$ & $0.70 \%$ & $1.09 \%$ & $-2.98 \%$ & $0.32 \%$ \\
\hline
\end{tabular}

Source: Authors' calculations based on Appendix Tables 1 and 2. 
Figure 6. Sources of real value added growth in the primary sector: 1885-1970 (period averages, annualized rates)

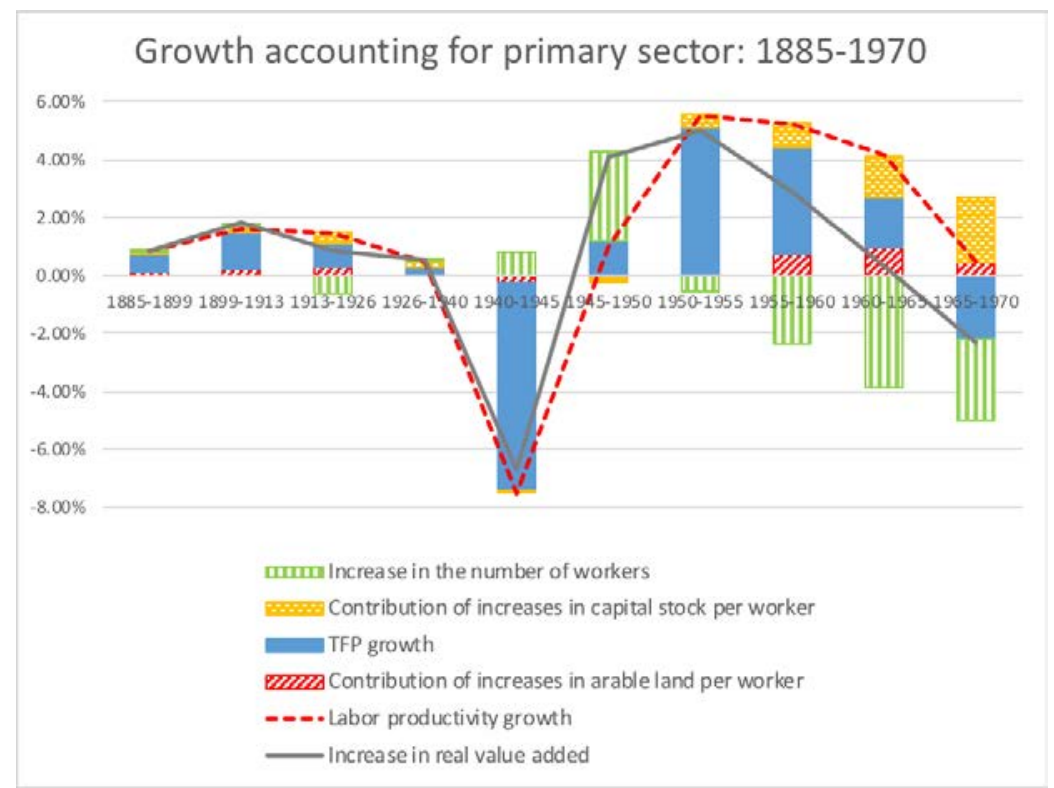

Source: See Table 1.

Figure 7. Cumulative contribution of increases in factors of production and TFP growth to labor productivity growth in the economy overall

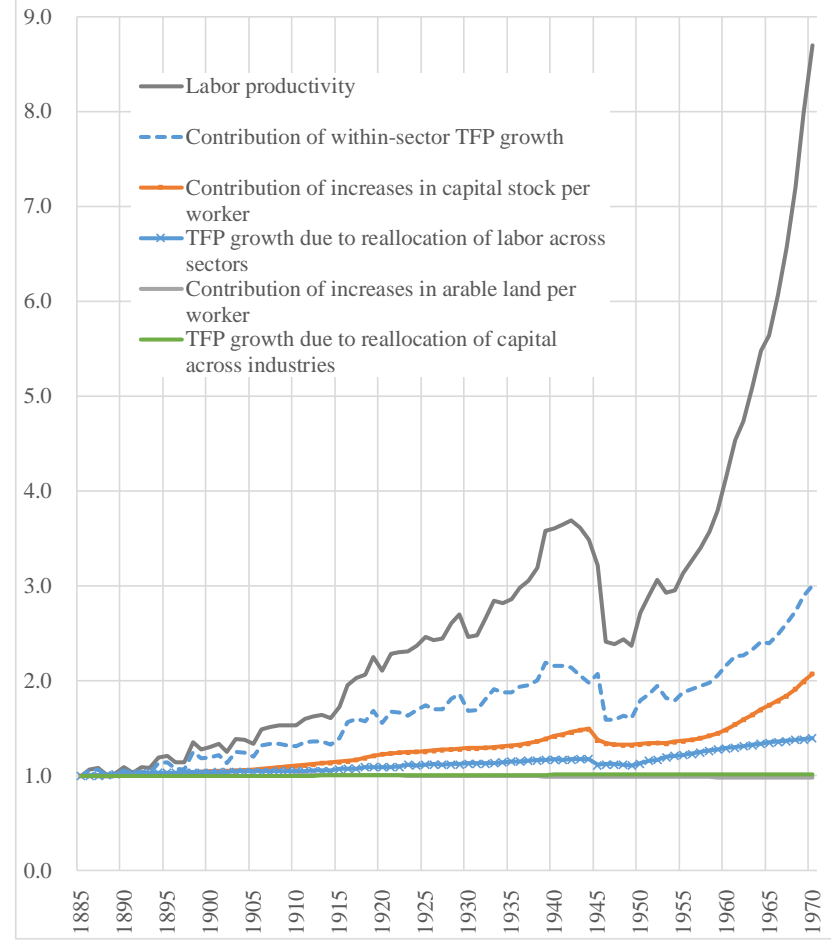


Thus, while it is likely that in the HSG era TFP growth includes the effect of improvements in the quality of labor and capital, the contribution of technological progress to economic growth cannot be ignored. On the other hand, for the prewar period it is difficult to obtain accurate data on labor quality and working hours, so that an analysis similar to the one for the postwar period is difficult. However, in their analysis of TFP growth in prewar Japan, Ohkawa and Rosovsky (1973) take these factors as much as possible into account. They conclude that although enrolment in primary education rose rapidly from the Meiji to the Showa era, so that the quality of labor clearly improved between 1900 and 1940, the impact of this on TFP growth was extremely limited. ${ }^{7}$

Turning to working hours, although Ohkawa and Rosovsky (1973) do not show the figures themselves, the way they estimate the rate of change in working hours by multiplying the rate of change in capital utilization rate by 0.5 suggests that (since the rate of change in the capital utilization rate is negative in most years) they assume that working hours decreased from 1900 to $1940 .{ }^{8}$ Furthermore, classic studies on working hours suggest that working hours in the manufacturing sector during the prewar period shortened, albeit slightly, due to growing labor activism and the gradual introduction of legal protection for workers such as the Factories Act, although this was compensated for by increases in work intensity.

Because our estimates do not take labor quality, working hours, work intensity, etc., into account, these factors are all included in the TFP growth rate, and at the moment, we cannot quantitatively examine their impact. Meanwhile, another factor that likely played an important role in driving TFP growth is the introduction of technology from abroad. During the interwar period, this mainly took the form of inward direct investment, while during the HSG period, licensing and firms’ own research and development (R\&D) efforts played an important role. For more details on inward direct investment in Japan

\footnotetext{
7 Ohkawa and Rosovsky (1973: 63-73).

8 See Ohkawa and Rosovsky (1973), pp. 60-62 and table 3-1 on p. 59. Data on labor quality in the prewar period measured in terms of working hours and years of education by Maddison (2007: 384), in line with Ohkawa and Rosovksy's assumption, suggests that throughout the prewar period (1820-1938) working hours per worker decreased while labor quality increased. However, the official statistics on working hours that Maddison probably relied on are not for actual working hours including overtime work and workers coming in for work early but for stipulated working hours (see Ohkawa and Rosovksy, 1973: 61, note 7). For an explanation of the working hours data by Maddison, see Maddison (1995: 242-243).
} 
during the interwar period, see Fukao and Settsu (2017c), while details on licensing and R\&D during the postwar period can be found in Fukao and Settsu (2018).

Finally, let us consider the contribution of increases in capital stock per worker. As seen in Table 3, the contribution of increases in capital stock per worker to labor productivity growth rose from 0.45 percentage points in the Meiji period to 0.83 percentage points in the Taisho and early Showa era and then jumped to 2.64 percentage points in the HSG era. Important reasons for this are that the acceleration of TFP growth in the HSG era and the acceleration of growth in the number of workers due to the labor market entry of the postwar baby boomer generation stimulated investment by raising the return on capital (Fukao and Settsu, 2017c) and that ample domestic savings for investment were available.

Let us take a closer look at the latter point. By definition, private investment in the economy overall ex post is equal to private savings minus the government deficit (government income minus government consumption including military expenditure plus public fixed capital formation) and lending overseas (current account surplus). Developments in this savings-investment balance are shown in Figure 8. Until around 1970, Japan's current account balance swung back and forth between surplus and deficit, and there was no large external borrowing. The figure shows that what made the vigorous private investment in the HSG era possible is, first, the increase in private savings and, second, the reduction of the government deficit and the return to surplus. The main reason why the government deficit shrank/turned into a surplus is that Japan was able to drastically reduce military expenditure under the Pax Americana after World War II (Fukao and Settsu, 2018). 
Figure 8: Japan's savings-investment balance: 1885-2014

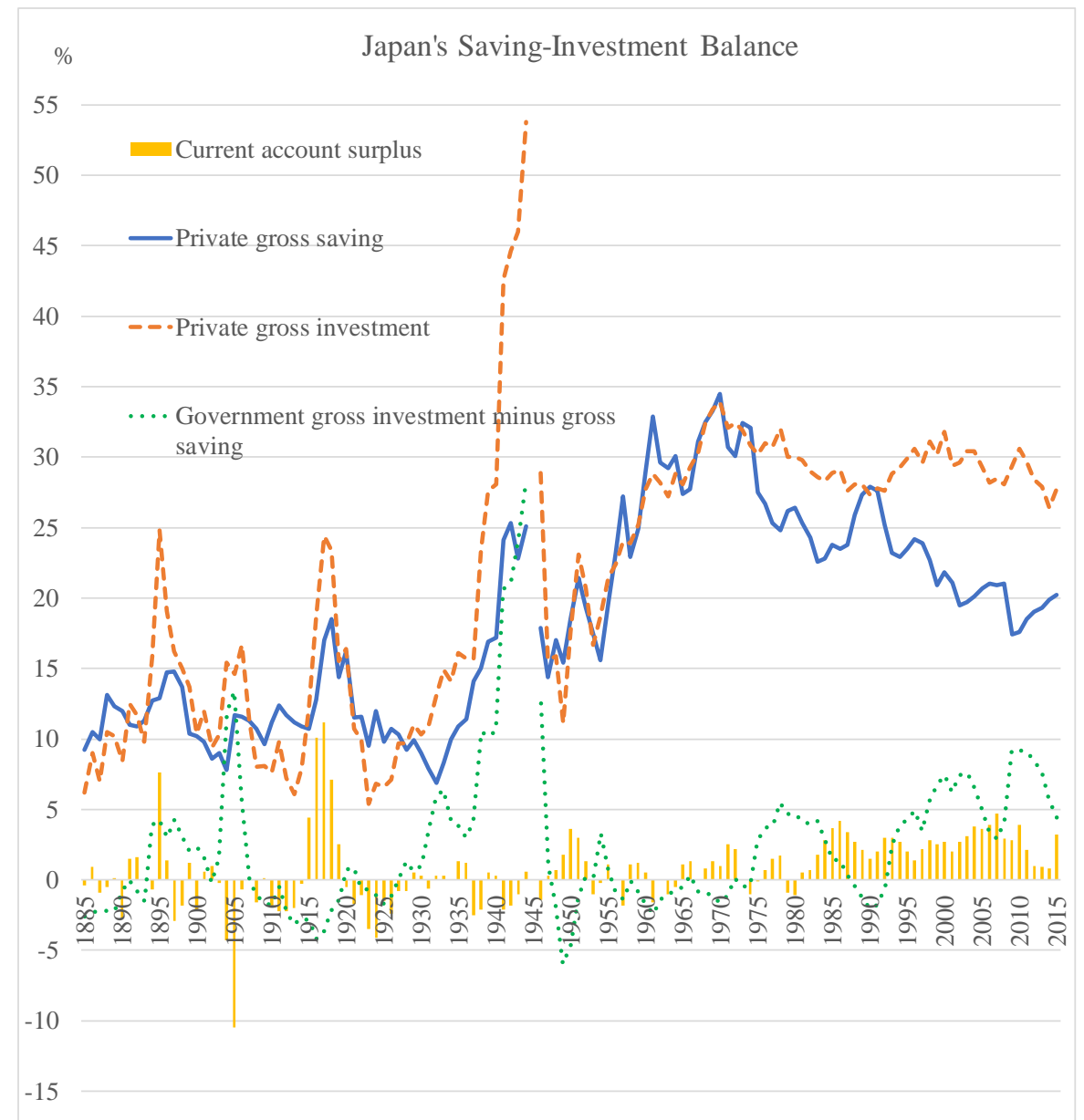

Sources: Fukao and Settsu (2018) and Fukao (2018).

\section{Conclusion}

Let us summarize the findings we obtained in this study. The key finding of our analysis is that labor productivity growth in Japan during the period we examined was driven primarily by TFP growth. This finding holds true both for the postwar period and the prewar period, although it needs to be noted that due to data limitations, our measure of TFP growth for the prewar period also includes the effect of factors such increases in labor quality and changes in working hours. Looking at developments by sector, we found the following.

Starting with the prewar period, the primary sector experienced substantial labor productivity growth during the period from 1899 to 1926 . However, whereas during the first half of that period (1899-1913), the main reason was TFP growth probably reflecting the spread of agricultural technology, during the second half (1913-26), the contribution 
of increases in capital stock per worker and arable land area per worker were relatively large. In the non-primary sector, TFP growth was the main driver of labor productivity growth almost through the entire prewar period.

Turning to the postwar period, Japan achieved remarkable rates of labor productivity growth during the high-speed growth era, driven again by TFP growth, but increases in the capital stock per worker also made a substantial contribution. Although these observations hold for both the primary and the non-primary sector, the growth rates in the latter were far higher than in the former. Overall, the results presented above show that the trend acceleration in Japan's economic growth was largely the result of two factors: first, the acceleration in within-sector TFP growth mainly in the non-primary sector; and second, the substantial increase in the contribution of increases in the capital stock per worker particularly during the high-speed growth era. 


\section{References}

Arimoto, Yutaka and Yoshihiro Sakane (2017) "Dai-san-sho Dai-issetsu, Nihon Nogyo to Noson Mondai [Chapter 3 Section 1: Japanese Agriculture and Rural Problem],” in Kyoji Fukao, Naofumi Nakamura, and Masaki Nakabayashi, Iwanami Koza: Nihon Keizai no Rekishi 4 Kindai 2 [Iwanami Lectures: Economic History of Japan, Vol. 4, Modern 2], Iwanami Shoten (in Japanese).

Emi, Koichi (1971) Shihon Keisei [Capital Formation], Long-Term Economic Statistics of Japan, Vol. 4, Toyo Keizai (in Japanese).

Francks, Penelope (1984) Technology and Agricultural Development in Pre-war Japan Front Cover, Yale University Press.

Fukao, Kyoji, and Tsutomu Miyagawa (2008) Seisansei to Nihon no Keizai Seicho - JIP Database ni Yoru Sangyo, Kigyo Level no Jissho Bunseki [Productivity and Japan's Economic Growth: Industry- and Firm-Level Analyses Based on the JIP Database], Tokyo: Tokyo University Press (in Japanese).

Fukao, Kyoji, Jean-Pascal Bassino, Tatsuji Makino, Ralph Paprzycki, Tokihiko Settsu, Masanori Takashima and Joji Tokui (2015) Regional Inequality and Industrial Structure in Japan: 1874-2008, Maruzen.

Fukao, Kyoji (2018) “Kanmatsu Furoku: Seisan, Bukka to Shotoku no Suikei [Appendix Tables: Estimation of Production, Prices and Income],” in Kyoji Fukao, Naofumi Nakamura and Masaki Nakabayashi, eds., Nihon Keizai no Rekishi, Iwanami Koza, Vol. 6, Gendai 2 [History of the Japanese Economy, Iwanami Lecture Series, Vol. 6, The Contemporary Period 2], Iwanami Shoten (in Japanese).

Fukao, Kyoji and Tokihiko Settsu (2017a) "Josho Dai-issetsu Seicho to Makuro Keizai [Introduction Section 1: Economic Growth and the Macroeconomy]," in Kyoji Fukao, Naofumi Nakamura, and Masaki Nakabayashi, Iwanami Koza: Nihon Keizai no Rekishi 4 Kindai-2 [Iwanami Lectures: Economic History of Japan, Vol. 4, The Modern Period 2], Iwanami Shoten (in Japanese).

Fukao, Kyoji and Tokihiko Settsu (2017b) “Kanmatsu Furoku: Seisan, Bukka to Shotoku no Suikei [Appendix Tables: Estimation of Production, Prices and Income],” in Kyoji Fukao, Naofumi Nakamura and Masaki Nakabayashi, eds., Nihon Keizai no Rekishi, Iwanami Koza, Vol. 4, Kindai 2 [History of the Japanese Economy, Iwanami Lecture Series, Vol. 4, The Modern Period 2], Iwanami Shoten (in Japanese).

Fukao, Kyoji and Tokihiko Settsu (2018a) "Josho Dai-issetsu Seicho to Makuro Keizai [Introduction Section 1: Economic Growth and the Macroeconomy]," in Kyoji Fukao, Naofumi Nakamura, and Masaki Nakabayashi, Iwanami Koza: Nihon Keizai 
no Rekishi 5 Gendai-1 [Iwanami Lectures: Economic History of Japan, Vol. 5, The Contemporary Period 1], Iwanami Shoten (in Japanese).

Fukao, Kyoji and Tokihiko Settsu (2018b) “Kanmatsu Furoku: Seisan, Bukka to Shotoku no Suikei (Appendix Tables: Estimation of Production, Prices and Income,” in Kyoji Fukao, Naofumi Nakamura and Masaki Nakabayashi, eds., Nihon Keizai no Rekishi, Iwanami Koza, Vol. 5, Gendai 1 [History of the Japanese Economy, Iwanami Lecture Series, Vol. 5, The Contemporary Period 1], Iwanami Shoten (in Japanese). Fukao, Kyoji, Tokihiko Settsu and Masaki Nakabayashi (2017) “Kanmatsu Furoku: Seisan, Bukka to Shotoku no Suikei [Appendix Tables: Estimation of Production, Prices and Income,” in Kyoji Fukao, Naofumi Nakamura and Masaki Nakabayashi, eds., Nihon Keizai no Rekishi, Iwanami Koza, Vol. 3, Kindai 1 [History of the Japanese Economy, Iwanami Lecture Series, Vol. 3, The Modern Period 1], Iwanami Shoten (in Japanese).

Fukao, Kyoji, Tsutomu Miyagawa, Joji Tokui, Tomohiko Inui and Sumio Hamagata (2008) "Nihon Keizai no Seicho Kaikei Bunseki [Growth Accounting Analysis of the Japanese Economy]," in Kyoji Fukao and Tsutomu Miyagawa, eds. Seisansei to Nihon no Keizai Seicho: JIP Database niyoru Sangyo/Kigyo Reberu no Jissho Bunseki [Productivity and Japan's Economic Growth, An Empirical Analysis at Industry and Firm Level Based on JIP Database], University of Tokyo Press (in Japanese).

Fukao, Kyoji and Tangjun Yuan (2016) "China's Growth Slowdown: Lessons from Japan's Experience and the Expected Impact on Japan, the USA and Germany," China and World Economy, vol. 24, no. 5, pp. 122-146.

Hayami, Yujiro (1973) Nihon Nogyo no Seicho Katei [The Growth Process of Japanese Agriculture], Sobunsha (in Japanese).

Hayashi, Fumio and Edward C. Prescott (2008) “The Depressing Effect of Agricultural Institutions on the Prewar Japanese Economy,” Journal of Political Economy, 116(4): 573-632.

Hayami, Yujiro and Vernon W. Ruttan (1985) Agricultural Development, Johns Hopkins University Press.

Jorgenson, Dale, Mun S Ho, Jon D Samuels, and Kevin J Stiroh (2007) “Industry Origins of the American Productivity Resurgence,” Economic Systems Research, 19(3): 229-252.

Jorgenson, Dale W., Koji Nomura and Jon D. Samuels (2016) “A Half Century of TransPacific Competition: Price Level Indices and Productivity Gaps for Japanese and U.S. Industries, 1955-2012,” in Dale W. Jorgenson, Kyoji Fukao and Marcel P. 
Timmer, eds., The World Economy: Growth or Stagnation? Cambridge University Press.

Keizai Shingicho, Kokumin Shotokuka (1954) Nihon Keizai to Kokumin Shotoku [Japan's Economy and National Income], Gakuyo Shobo (in Japanese).

Komiya, Ryutaro (1975) Gendai Nihon Keizai Kenkyu [A Study of the Contemporary Japanese Economy], Tokyo University Press (in Japanese).

Maddison, Angus (1995) Monitoring the World Economy 1820-1992, OECD.

Maddison, Angus (2006) The World Economy, OECD.

Maddison, Angus (2007) Contours of The World Economy, 1-2030 AD, Oxford University Press.

Makino, Tatsuji (2019) “1885-1970-nen ni Okeru Shihon Suikei [Capital Estimates for 1885-1970],” Institute of Economic Research, Hitotsubashi University (in Japanese). Minami, Ryoshin and Fumio Makino (2002) Nihon no Keizai Hatten Dai-3-ban [Japan's Economic Development, $3^{\text {rd }}$ Edition], Toyo Keizai (in Japanese).

Mizoguchi, Toshiyuki and Noriyuki Nojima (1993) “1940-1955-nen ni okeru Kokumin Keizai Keisan no Ginmi [Nominal and Real GDP of Japan: 1940-1955,” in Toshiyuki Mizoguchi, ed., Dai-2-ji Taisen-ka no Nihon Keizai no Tokei-teki Bunseki [Statistical Analysis of Japan's Economy During World War Two], 1990-1992 JSPS Grant-in-Aid for Scientific Research Report (in Japanese).

Ohkawa, Kazushi, Shigeru Ishiwata, Saburo Yamada and Hiromitsu Ishi (1966) Shihon Sutokku [Capital Stock], Long-Term Economic Statistics of Japan, vol. 3, Tokyo: Toyo Keizai (in Japanese).

Ohkawa, Kazushi, Tsutomu Noda, Nobukiyo Takamatsu, Saburo Yamada, Minoru Kumazaki, Yuichi Shionoya, and Ryoshin Minami (1967) Bukka [Prices], LongTerm Economic Statistics of Japan, vol. 8, Tokyo: Toyo Keizai (in Japanese).

Ohkawa, Kazushi and Henry Rosovsky (1973) Japanese Economic Growth: Trend Acceleration in the Twentieth Century, Stanford University Press.

Ohkawa, Kazushi and Miyohei Shinohara, eds. (1979) Patterns of Japanese Economic Development: A Quantitative Appraisal, Yale University Press.

Ohkawa, Kazushi, Nobuyoku Takamatsu, and Yuzo Yamamoto (1974) Kokumin Shotoku [National Income], Long-Term Economic Statistics of Japan, vol. 1, Tokyo: Toyo Keizai.

Sakane, Yoshihiro and Yutaka Arimoto (2017) “Dai-san-sho Dai-issetsu, Kogyoka-ki no Nihon Nogyo [Chapter 3 Section 1: Japanese Agriculture during the Industrialization Period]," in Kyoji Fukao, Naofumi Nakamura, and Masaki Nakabayashi, Iwanami Koza: Nihon Keizai no Rekishi 3 Kindai 1 [Iwanami 
Lectures: Economic History of Japan, Vol. 3, Modern 1], Iwanami Shoten (in Japanese).

Settsu, Tokihiko (2009), “Daisanjisangyo shotoku no saisuikei: ‘Choki keizai tokei’ kaitei no kokoromi [Revision of National Income Estimates on the Tertiary Industry in Pre-war Japan: An Approach to Examining Long-Term Economic Statistics],” Keizai Kenkyu [Economic Review], 60(2): 97-111 (in Japanese).

Sonobe, Tetsushi and Keijiro Otsuka (2001) “A New Decomposition Approach to Growth Accounting: Derivation of the Formula and Its Application to Prewar Japan,” Japan and the World Economy, 13: 1-14.

Umemura, Mataji, Saburo Yamada, Yujiro Hayami, Nobukiyo Takamatsu, and Minoru Kumazaki (1966) Noringyo [Agriculture and Forestry], Long-Term Economic Statstics, Vol. 9, Tokyo: Toyo Keizai (in Japanese).

Utsumi, Yoshio (1959) Rodo Jikan no Rekishi [A History of Working Hours], Otsuki Shoten (in Japanese).

Yagi, Hironori (1990) “Nogyo [Agriculture],” in Shunsaku Nichikawa and Takeshi Abe, eds., Nihon Keizai-shi 4, Sangyo-ka no Jidai 1 [Japanese Economic History 4, Age of Industrialization 1], Iwanami Shoten (in Japanese).

Yuan, Tangjun, Tokihiko Settsu Jean-Pascal Bassino, and Kyoji Fukao (2009) "Senzenki Nihon no Kennai Soseisan to Sangyokozo [Gross Prefectural Domestic Product and Industrial Structure in Pre-War Japan, 1890-1940]," Keizai Kenkyu [Economic Review], 60(2): 163-189 (in Japanese). 


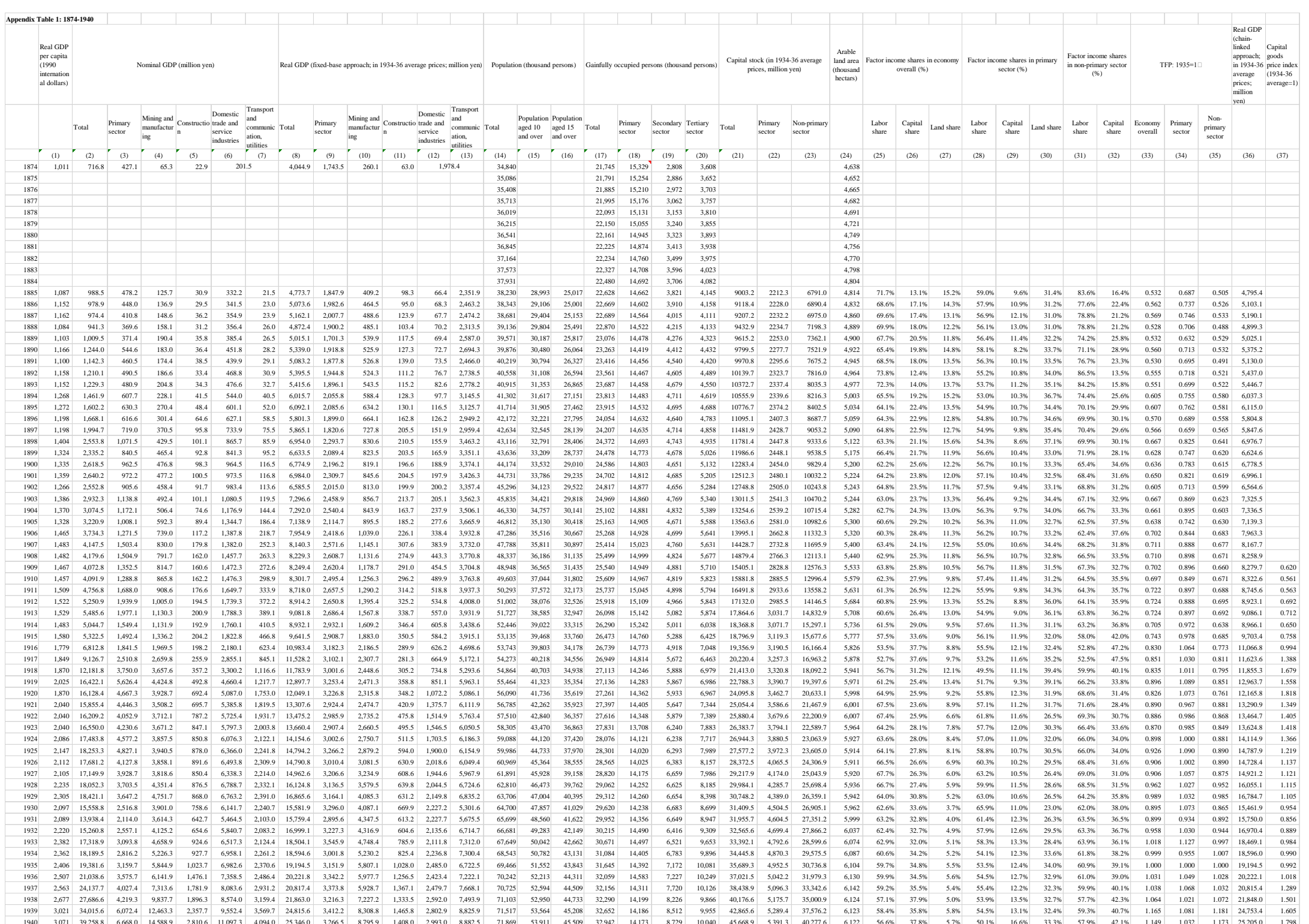


Notes and source:

Column (1): Based on Settsu, Bassino, and Fukao (2016).

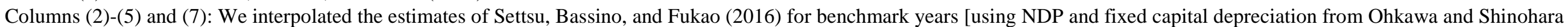

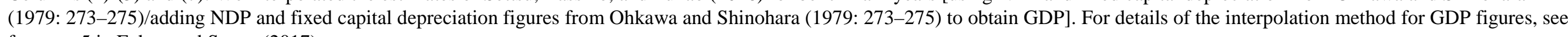
footnote 5 in Fukao and Settsu (2017).

Column (6): The estimates of Settsu, Bassino, and Fukao (2016) were complemented using the values from Settsu (2009) corrected for errors (see https://hermes-ir.lib.hit-

u.ac.jp/rs/handle/10086/19558) plus fixed capital depreciation and imputed rent.

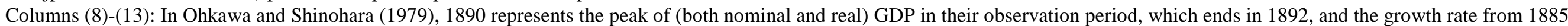

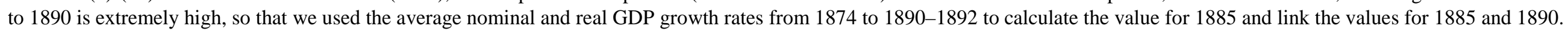

Column (14): Year-end de facto population. For details of the estimation method, see Yuan et al. (2009).

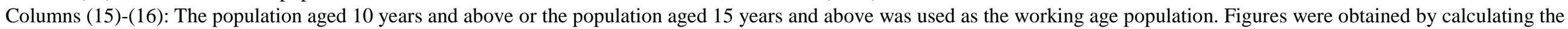
population share of each based on figures from Umemura et al. (1988: 166-171, tables 1 and 2) and then multiplying these shares by the population in column (14).

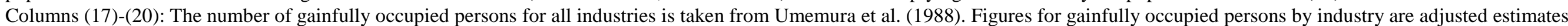

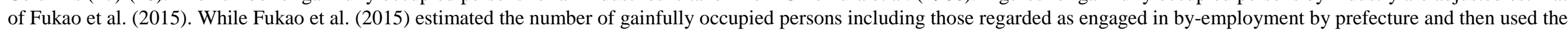
sum as the national total, in this study we used the number of gainfully occupied persons including those regarded as engaged in by-employment estimated for Japan as a whole.

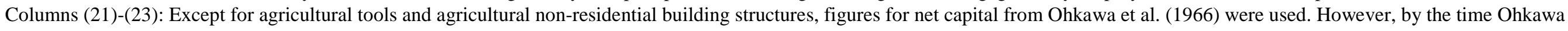

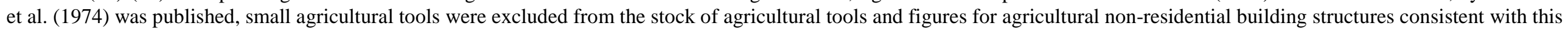

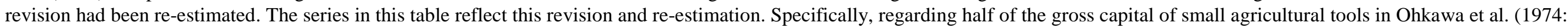

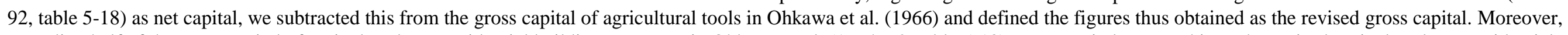

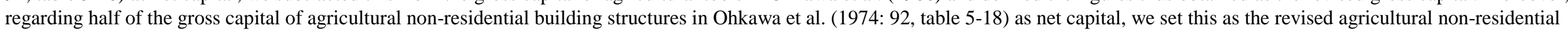

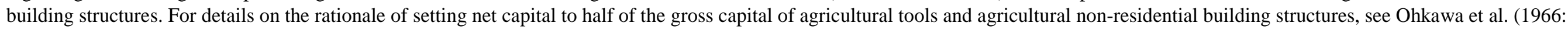
114 and 107-108).

Column (24): We used the arable land area from Hayami (1973: 205-207, appendix table C-4).

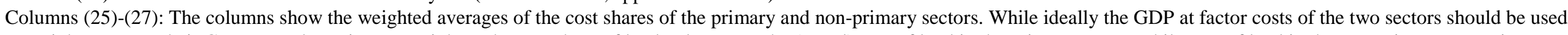

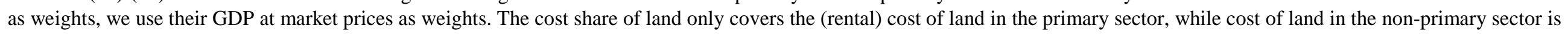
included in the cost share of capital.

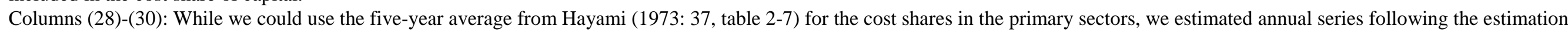

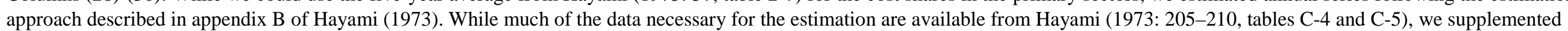

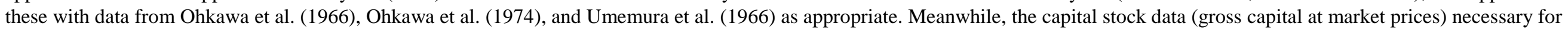

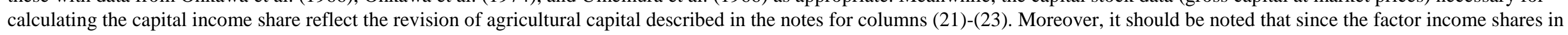
agriculture are used as cost shares in the primary sector, we assume that cost shares in agriculture, forestry, and fisheries are identical.

Columns (31)-(32): The data are taken from Ohkawa and Minami (1975: 616-617, appendix table 18).

Columns (33)-(35): See Section 2 of this paper for an explanation of the estimation method.

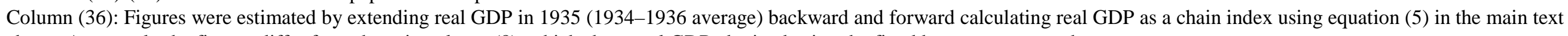
above. As a result, the figures differ from those in column (8), which show real GDP obtained using the fixed base year approach.

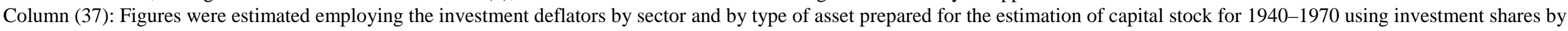
sector and by type of asset (1934 -1936 average) as weights. For details, refer to the notes and sources for Appendix Table 2. 


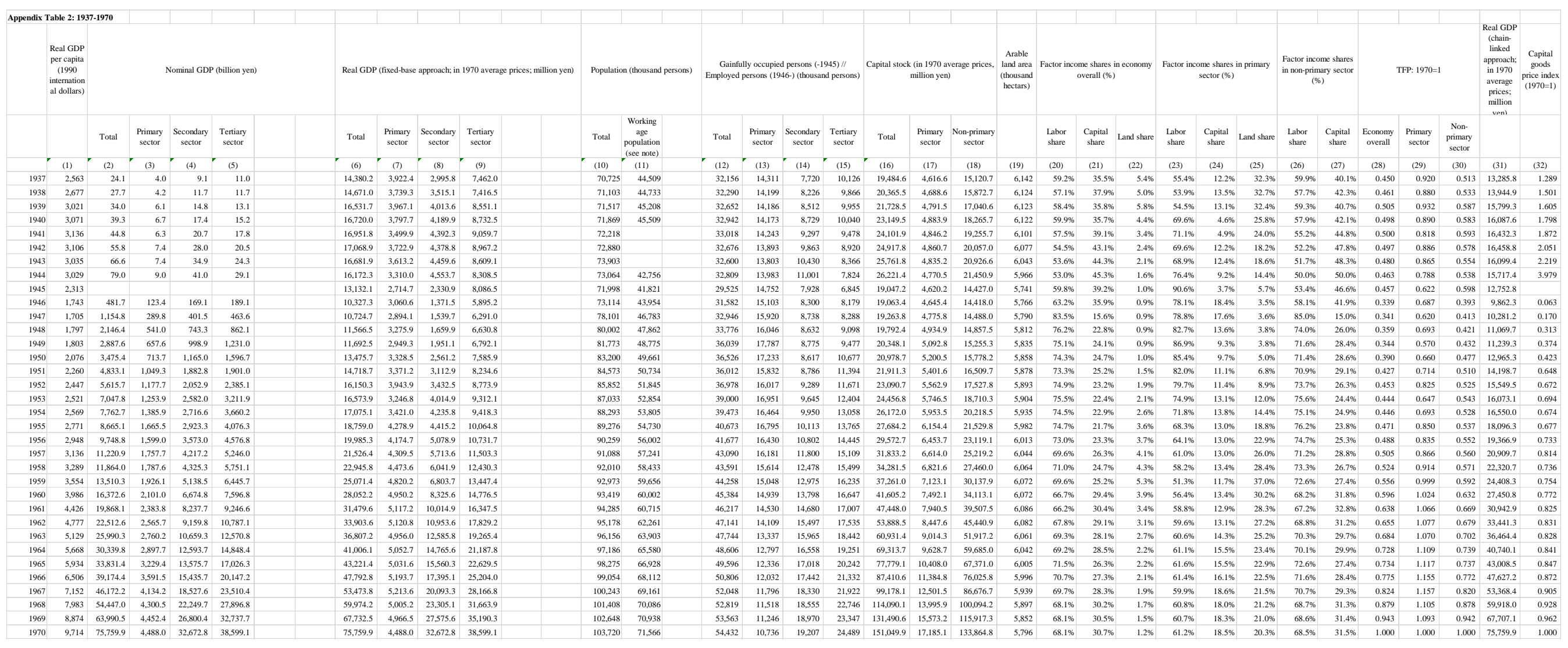

\section{Notes and source:}

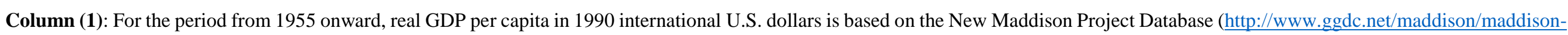

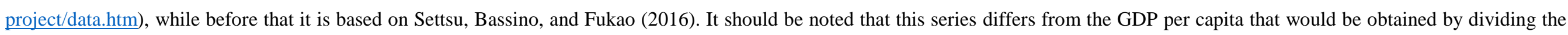

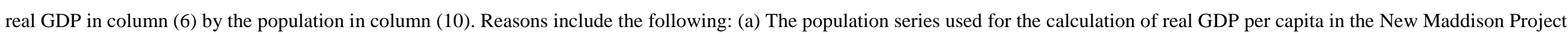

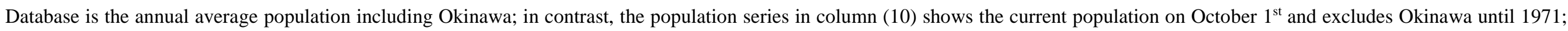

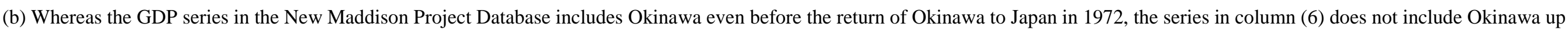
to 1972 . 


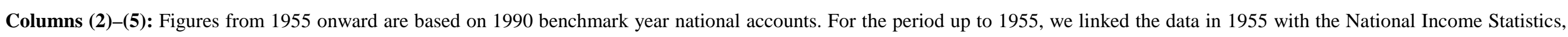
1965 Benchmark Year, and in 1952 with data from Keizai Shingicho Kokumin Shotokuka (1954) Nihon Keizai to Kokumin Shotoku.

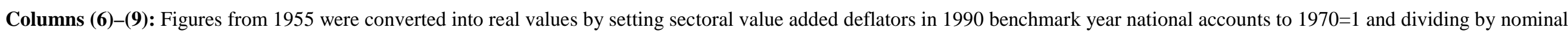
values. For the period up to 1955, we linked the data in 1955 with the data in Mizoguchi and Nojima (1993).

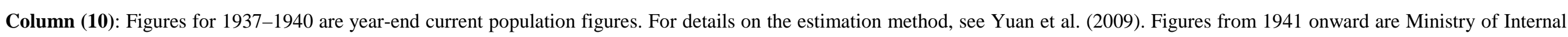

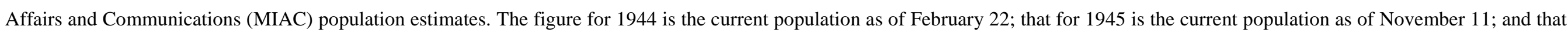

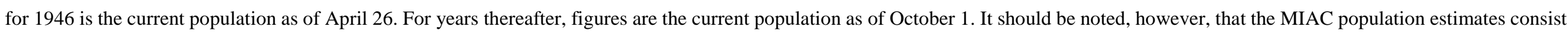

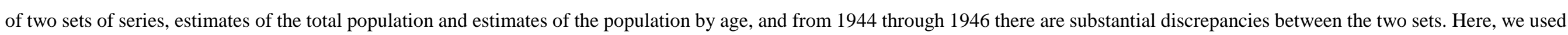

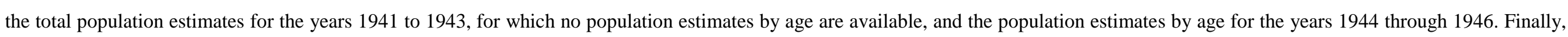
Okinawa is not included from 1947 through 1971.

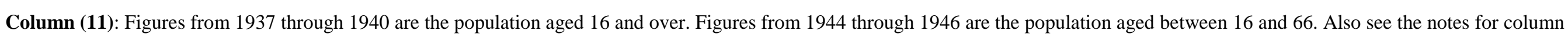
(10) for figures up to 1946.

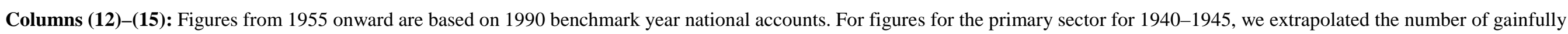

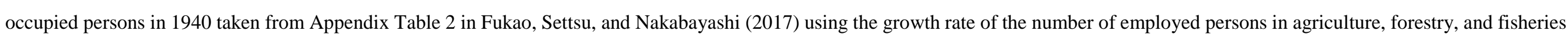

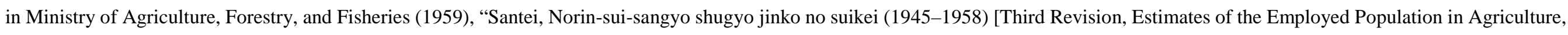

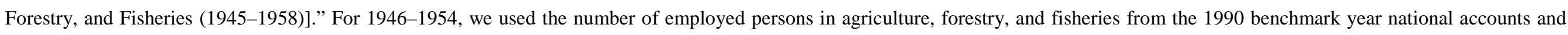

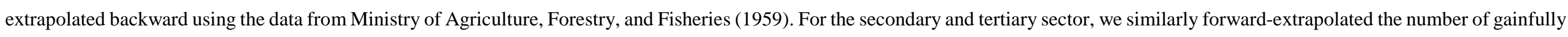

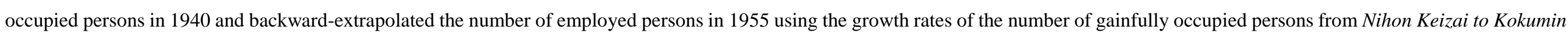
Shotoku and 1965 benchmark year national income statistics.

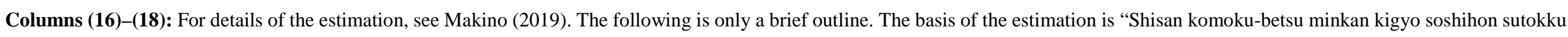

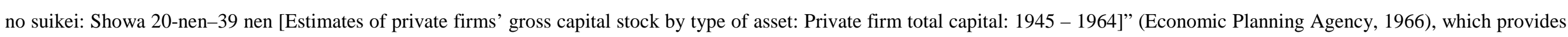

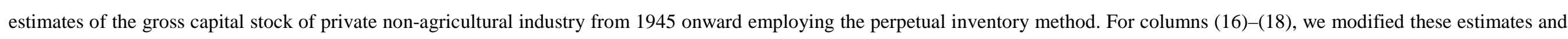

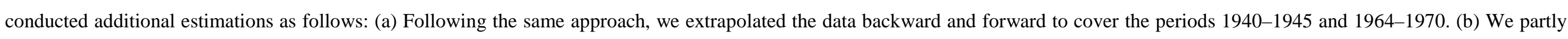

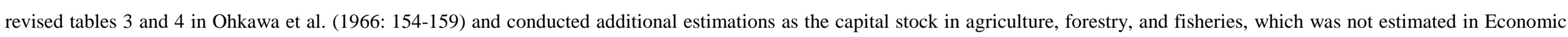

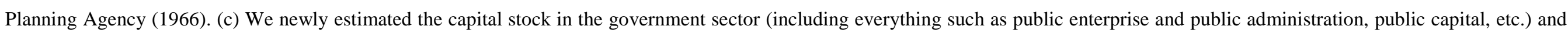




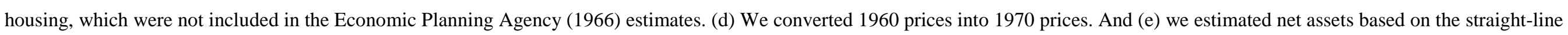
depreciation, which was also used in the LTES.

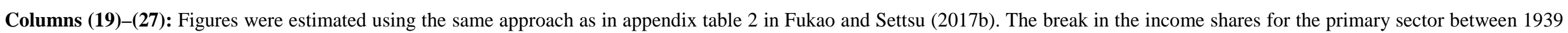

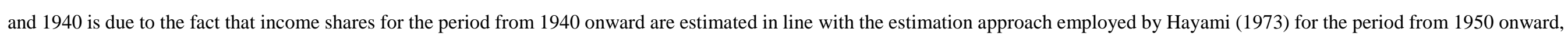
while the figures for 1937-1939 are based on Hayami’s (1973) estimation approach for the period up to 1940, and we did not make any adjustments for this.

Columns (28)-(30): For details of the growth accounting, refer to the main text and see Fukao, Makino, and Settsu (2017).

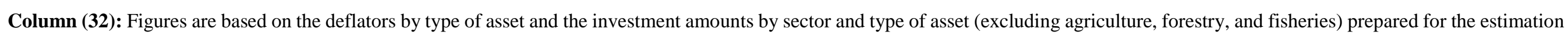

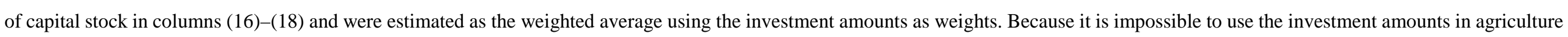
(see the note of columns (16)-(18)), agriculture, forestry and fisheries is excluded to calculate the weights. 